\title{
Tudo o que sei é ela que me ensina: o menino Drummond na Biblioteca
}

\author{
Silvana Maria Pessoa de Oliveira \\ Universidade Federal de Minas Gerais
}

\begin{abstract}
Essa criança é uma coisa que está nos meus dedos. 'As vezes debruço-me sobre as cisternas, e as vertigens, e as virilhas em chamas.

È a minha vida. Mas essa criança

É tão brusca, tão brusca, ela destrói e aumenta O meu coração.
\end{abstract}

(Herberto Helder)

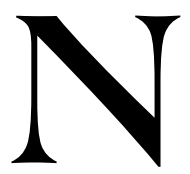

ota-se, na poesia drummondiana, uma série de referências às atividades de leitura e escrita, praticadas por um sujeito que freqüentemente adota a perspectiva da criança. Notadamente em Boitempo encontra-se um conjunto de sete poemas que revelam, de maneira explícita, o modo como Drummond, tornado menino, lê e conseqüentemente esboça os seus primeiros exercícios de escrita. À maneira dos supostos "livros de formação", Boitempo pretende construir, poeticamente, a infância e adolescência de um futuro escritor, através do mergulho em um tempo e espaço determinados, a saber, as duas primeiras décadas do século $\mathrm{XX}$, na pequena Itabira, a princípio e, posteriormente, na ainda provinciana Belo Horizonte. Neste contexto, a aprendizagem da leitura e da escrita pode ser vista como etapa fundamental do processo de constituição da subjetividade de um poeta que se apresentará como um sujeito de memória ciente da dificuldade que envolve qualquer pretensa tentativa de recuperação da vivência de um passado. Haverá sempre um desajuste - entre o vivido e o que dele se pode contar - de onde decorrem tanto o sentimento de perda irrecuperável como uma certa leveza que faz com que essa perda se ultrapasse a si mesma: o que se dissipou, afinal, era já ficção. 
A imagem do menino que lê já se encontra presente em Alguma poesia, obra de estréia de Carlos Drummond de Andrade. "Infância" é o segundo poema do livro, vindo logo após "Poema de sete faces", pórtico da obra e espécie de síntese programática desta poesia. Em "Infância" determinados aspectos ligados a um certo ritual da leitura aparecem enfatizados. O ambiente natural dos campos natais, encimado pela casa ancestral da família - que será mais tarde recorrentemente explorado em Boitempo - será o cenário onde um menino solitário lê a história de Robinson Crusoé, comprida história que não acaba mais. A calmaria que emana de uma sucessão de quadros da vida idílica, marcada por relações familiares também idílicas, parece não satisfazer o menino, que projeta na história de Robinson seu desejo de evasão. A ligação da vida e dos seus acontecimentos a um lugar situado em um pequeno mundo limitado no espaço contrasta com a vastidão dos mares percorridos pelo herói de Defoe e pode evidenciar a dificuldade de adesão à vida que, na visão de Antonio Candido, definiria o eu expresso pela primeira pessoa nos versos de Drummond. Em crônica de 1952, intitulada "Divagação sobre as ilhas", pode-se perceber a postura de relativa ambigüidade no que concerne à posição do poeta frente ao mundo. A ilha é, simultaneamente, espaço metafórico que permite o isolamento e local de reflexão sobre a vida em sociedade. Observe-se o seguinte fragmento:

Minha ilha (e só de a imaginar já me considero seu habitante) ficará no justo ponto de latitude e longitude que, pondo-me a coberto de areias, sereias e pestes, nem me afaste demasiado dos homens nem me obrigue a praticá-los diuturnamente. Porque esta é a ciência e, direi, a arte do bem viver; uma fuga relativa, e uma não muito estouvada confraternização. ${ }^{1}$

Tanto no poema quanto na crônica, a referência ao náufrago solitário pode ser um bom indicador para pensar os desdobramentos que uma possível figuração do leitor assumirá em Drummond. Se em "Infância" o mato sem fim da fazenda sugere o ideal de um espaço bucólico propício à iniciação literária do menino, pode-se, por outro lado, perceber como o mesmo espaço será útil para outro tipo de experiência, desta vez não mais solitária, mas compartilhada: a amorosa. Essa aprendizagem é a que se faz representar no poema "Iniciação Amorosa" também de Alguma Poesia. Há certas

\footnotetext{
${ }^{1}$ ANDRADE, 1992, p. 1376.
} 
referências coincidentes entre ambos os poemas: a sombra das mangueiras como local destinado ao deleite, tanto da leitura quanto do amor. As mangueiras são o suporte para a rede que sustém os corpos na "confluência do amor", mas também proporcionam o refúgio tranqüilo para a leitura das histórias.

A iniciação ocorre, pois, em dois planos e parece comportar certos rituais que podem ser vistos seja como etapas preparatórias para se atingir determinados objetivos seja como exercícios de aprendizagem da poesia. É curioso notar que o poeta estreante de Alguma poesia-aquele que figura o menino ávido por histórias de aventuras - possa retornar posteriormente sob a pele de um sujeito de memória que, tendo já protagonizado uma história (agora sim) mais bonita que a de Robinson Crusoé assuma-se como cantor da família como grupo e tradição, para usar os termos empregados por Antonio Candido em famoso estudo sobre a poesia drummondiana.

Nesse sentido, a infância talvez interesse a Drummond muito mais como lugar de convívio com os livros do que como idealização feliz de uma época, crença à qual o poeta parece nunca ter sido simpático. Os poemas de Boitempo intitulados "Primeiro conto", "Primeiro jornal", "Iniciação Literária", "Fim", "Assinantes" e "Biblioteca Verde" são exemplares privilegiados desta disposição. Por outro lado, a constatação da existência de um não-saber como atributo próprio ao menino mostra-se evidente em "Primeiro conto". No poema, o candidato a escritor vê-se às voltas com a difícil tarefa de dar vazão, na escrita, às emoções e sentimentos que se mostram, então, refratários à expressão poética:

O menino ambicioso

Não de poder ou glória

Mas de soltar a coisa

Oculta no seu peito

Escreve no caderno

E vagamente conta

À maneira de sonho

Sem sentido nem forma

Aquilo que não sabe. ${ }^{2}$

Escrever é, num certo sentido, a tentativa de ordenar o caos da experiência interior. É curioso observar que a referida estrofe mostra-se aparentada ao verso e eu não sabia que a minha história/ era mais bonita

\footnotetext{
${ }^{2}$ ANDRADE, 1992, p. 548.
} 
que a de Robinson Crusoé, que está no final do poema "Infância". A dificuldade que envolve, para o menino, o duro duro duro oficio de escrever talvez esteja relacionada à necessária aprendizagem de certos rituais da escrita. O menino que não sabe expressar seus sentimentos dá lugar ao homem que, tendo conquistado, através da luta com as palavras, a expressão adequada, já não pode, contudo, sentir como antes sentira. O descompasso entre a expressão do menino e a expressão do homem permanecerá insolúvel:

Quem decifra por baixo

A letra do menino

Agora que o homem sabe

Dizer o que não se oculta no seu peito?3

O "menino" afigura-se como aquele ser incapaz de conferir, adequadamente, forma e sentido à experiência, ao passo que o "homem" é quem, tendo pretensamente dominado a técnica e os materiais da escrita, pode usar as palavras para expressar-se à vontade. Idêntica situação apresenta-se no poema "Primeiro jornal" - também de Boitempo-em que o sujeito poético inveja o jovem companheiro, redator de um pequeno jornal manuscrito. Na impossibilidade de imitar a contento o colega, restalhe a leitura "humilhada" do periódico. É como se o poeta se tornasse consciente de que o escrever demanda, antes de mais, uma aprendizagem que passa, sobretudo, pela necessária experiência da leitura.

Em "Iniciação Literária" retoma-se a idéia do menino que sonha sair pelo mundo/voando na capa vermelha de Júlio Verne. Os livros de aventura, repletos de heróis destemidos, povoam a imaginação do menino Drummond. O devaneio da criança lembra as fantasias do pequeno Robinson, fugitivo de sua história, que deseja que a leitura possa funcionar como algum ponto de ancoragem.

Contudo, um possível esvaziamento do sonho pode ser visto nos poemas "Infância" e "Iniciação Literária", em que a referência ao universo rural, representado pelo espaço amplo e arcaico da fazenda - espécie de porto seguro para o menino - com seus pastos sem fim, seus animais e personagens obrigam a criança a mergulhar na história concreta que o circunda. Em "Iniciação Literária", uma obra didática sobre a cultura dos campos permite, de maneira irônica, estabelecer com o mundo repleto de

3 ANDRADE, 1992, p. 548-549. 
aventuras fantásticas presentes nos livros de Júlio Verne um contraste evidente.

Os produtos agropecuários - prosaicos e cotidianos - contrastam com os fabulosos navios de Júlio Verne, inscrevendo, no espaço do sonho e da evasão, a crua luz do real. Nesse sentido, a iniciação literária do menino Drummond é marcada pela distinção entre a realidade comezinha dos trabalhos agrários e o conseqüente desejo de fuga para os paraísos imaginários construídos pela ficção de Júlio Verne. Trata-se da exposição de um conflito cujo motivador é a leitura. Esse conflito põe em evidência a tensa relação do menino com as histórias lidas e com o tempo histórico que serve de cenário para tais leituras.

Habitar as ilhas seria, para o pequeno sonhador, o ideal. Mas as histórias precisam chegar ao fim, assim como o menino precisa encarar novas possibilidades de sentido, outras leituras. Entra, então, em cena a Biblioteca Verde. É o momento em que as revistas Tico-Ticoe Careta cedem espaço aos 24 volumes encadernados da Biblioteca Internacional de Obras Célebres. A leitura agora se diversifica, se amplia, já anunciando os primeiros passos na formação de um leitor exigente, capaz de perceber realidades mais complexas: Templo de Tebas. Osíris, Medusa, Apolo nu, Vênus nua... Nossa Senhora, tem disso nos livros? Não se trata mais do garoto isolado, seduzido por histórias de aventuras lidas e relidas. É agora a oportunidade de encontro com um saber mais abrangente, que se metaforiza através da imagem da biblioteca de obras célebres. Trata-se, agora, não mais da criança sozinha entre mangueiras, no espaço bucólico e pastoril da fazenda paterna, mas do leitor imerso no vasto e diversificado mundo da biblioteca.

A biblioteca configura-se como tesouro, manancial inesgotável de onde se pode usufruir o conhecimento. A chegada à casa paterna dos livros representa para o menino um divisor de águas, um ritual de iniciação. Deixase para trás a infância, mergulha-se no universo "adulto" das obras canônicas. Após a chegada dos livros, o jovem pode declarar

Tudo que sei é ela que me ensina.

O que saberei, o que não saberei

nunca

está na Biblioteca em verde murmúrio

de flauta-percalina eternamente. ${ }^{4}$

${ }^{4}$ ANDRADE, 1992, p. 552. 
Não sem razão, a cor verde presente na lombada dos livros lembra a antiga ligação do menino com a fazenda paterna. Vista agora como reserva de saber, como tesouro disponível à consulta, a coleção marca a opção do menino drummondiano por um saber até certo ponto livresco e erudito, passível de ser ordenado, selecionado. O acesso do menino à Biblioteca Internacional de Obras Célebres apresenta-se, pois, como marco inaugural de um périplo de leitura por mundos múltiplos e fascinantes, numa aventura que é, sobretudo, uma aventura na linguagem.

Ao prazer da leitura associa-se, num duplo movimento, o prazer da escrita. Se, para o menino drummondiano, a leitura constitui-se em antídoto eficaz contra a monotonia e a aspereza do cotidiano, porque dela depende a capacidade de multiplicar imaginariamente vivências, percepções e sensações, ela é também a possibilidade de olhar o mundo com o maior número de olhos possível. O exame da trajetória das leituras encenadas, via memória, nos poemas de Boitempo permite avaliar o valor que o ato de ler assumirá na arte poética drummondiana, aqui pensada como ponto de confluência das linhas secretas que, na poesia, aglutinam tanto a palavra lida quanto a palavra escrita.

\section{Referências Bibliográficas}

ANDRADE, Carlos Drummond de. Poesia e prosa - volume único. Rio de Janeiro: Editora Nova Aguillar, 1992. 8. ed.

CANDIDO, Antonio. "Inquietudes na poesia de Drummond". Vários escritos. 3 ed. Revista e ampliada. São Paulo: Duas Cidades, 1995. p. 111-145.

\section{Resumo}

Análise de poemas de Carlos Drummond de Andrade com o objetivo de refletir sobre o modo como, nessa poesia, expõem-se as relações entre infância e leitura.

\section{Résumé}

Analyse des poèmes de Carlos Drummond de Andrade pour mettre en évidence les rapports, dans cette poésie, entre l'enfance et la lecture. 